\section{Eating One's Way through Cultures: Antonin Artaud's Autoexoticist Diets and Epistemologies}

\author{
XIAOFAN AMY LI
}

XIAOFAN AMY LI is lecturer in comparative literature at the University of Kent, Canterbury. Her research focuses on comparisons between French and Chinese literature and culture, spanning topics such as intercultural encounters, the reception of Chinese antiquity in twentieth-century France, French ethnographic fiction, and Chinese poetics. She is working on her second monograph, a comparative study on play in literature and the arts.
THAT CULTURE, DIET, AND EPISTEMOLOGY ARE INTERTWINED AND FORMULATE ONE ANOTHER IS A TRUISM. BUT TO SEE THEM AS ONE LIVING body inhabiting shifting perspectives that can be shed easily, like snakeskins, is an exotic view that invites further investigation. Such intriguing ideas are precisely what we find in the remarkable avantgarde writer Antonin Artaud (1896-1948). This essay traces the surprising connections between Artaud's idea of culture, the body, diet, and knowledge, arguing that Artaud outlines a notion of autoexoticism as throwing open the boundaries of one's subjectivity and culture to change and rupture.

\section{Metaphors of Food, Knowledge, and Cultural Systems}

Food and knowledge are often paired. A most famous example is the fruit, usually depicted as an apple, of the tree of knowledge of good and evil. On eating it, Adam and Eve gained self-consciousness and were expelled from Eden as a result. Some important parallels between eating and acquiring knowledge emerge from this story: both activities are extremely intimate and intrusive, in that they allow something foreign to enter you and then become an integral and constituent part of you; your food travels inside your body, just as new knowledge enters your thoughts and can affect your acts and emotions. Nor can you refuse their intrusion, because the maintenance of your body and identity depends on constantly receiving food and knowledge from the outside. In other words, you remain yourself by changing. The refusal to eat is usually related to some mental or existential malaise, whereas the refusal to know is fundamentally a refusal to be changed, to enter into any relation with or depend on anything other than yourself, or to exist in a social community. This is manifested in Artaud's identification of bodily organism with cultural system.

Culture enters into the food-knowledge analogy when different ways of eating and knowing are correlated with different ways of organizing life and experiencing the world. Rites and interdictions

(C) 2017 XIAOFAN AMY LI

PMLA 132.2 (2017), published by the Modern Language Association of America 
are often established around both food and knowledge, and such formulations of belief and behavior are the basis of any cultural system. Claude Lévi-Strauss argued that culture and nature could be understood in binary correlations to different diets and knowledge structures: the raw and cooked, the fresh and decayed, the diachronic and synchronic readings of myth $(\mathrm{Cru})$. In Tristes tropiques, he divided cultures into anthropophagous and anthropoemic societies (émein, "to vomit"), arguing that primitive societies "voient dans l'absorption de certains individus détenteurs de forces redoutables le seul moyen de neutraliser celles-ci, et même de les mettre à profit" 'deal with strangers and deviants by swallowing them up, by making them their own, even by gaining strength from them' and are therefore anthropophagic; whereas modern Western societies are anthropoemic because they "expuls[ent] ces êtres redoutables hors du corps social en les tenant temporairement ou définitivement isolés, ... dans des établissements destinés à cet usage" 'vomit out these deviants, keeping them outside society by temporarily enclosing them or permanently isolating them ... in special institutions designed for this function' (464). This purging impulse of Western modernity contributed greatly to the othering process in Western exoticist representations. Theories of culture have gone well beyond Lévi-Strauss's structuralist binaries, but his metaphors of cannibalism and purging for different cultures still offer food for thought. In this essay, I explore along these lines of metaphoric thought the ideas of culture in Artaud and how they connect to an autoexoticism of cultural fluidity and self-fashioning.

\section{Culture as Organism and Artaud's Anorexic Autoexoticism}

Nothing could be further from Artaud's notion of culture than well-preserved books, museums, monumental architecture, or es- tablished traditions of thought. For Artaud, culture is a living organism and cannot reside in lifeless things:

Il faut insister sur cette idée de la culture en action et qui devient en nous comme un nouvel organe, une sorte de souffle second.

(Euvres complètes 4: 12)

We must insist on the idea of culture in action, which grows within us like a new organ, a sort of second breath.

Protestation contre le rétrécissement insensé que l'on impose à l'idée de culture en la réduisant à une sorte d'inconcevable panthéon ... contre l'idée séparée que l'on se fait de la culture, comme s'il y avait la culture d'un côté et la vie de l'autre.

A protest against the senseless constraint imposed on the idea of culture by reducing it to a sort of inconceivable pantheon, ... against the idea of culture separated from life, as if there were culture on one side and life on the other.

Culture is synonymous with life, is a biological corpus in "le mouvement incessant" 'constant movement,' and depends on the circulation of vital forces and regeneration to stay alive. The old therefore needs to be shed to make room for the new, lest culture become petrified forms of aesthetics, thought, and society. "Être cultivé c'est brûler des formes, brûler des formes pour gagner la vie" 'To be cultivated is to burn forms, burn forms in order to attain life' (8: 202), "car pas de culture sans foyer" 'because culture cannot exist without the furnace' (160). This logic of facies destruens ("to destroy in order to create") with regard to cultural renewal was vehemently expounded by Artaud when he talked about the malaise of Europe in his time (1920s-40s). In his view, European culture and society were rotten to the core and had lost all claim to civilization, being instead a "barbarie" 'barbarity' (8: 157) that entertained a bourgeois "idée paresseuse" 
'lazy idea' (4: 15) of art as leisure. Europe was similar to a hopelessly infected body, and for Artaud the solution was not to heal it but to destroy it. A cathartic purging was the most salutary treatment for Europe, as Artaud emphasized in his Théâtre et son double ("The Theater and Its Double") and Mexican writings, and this purging was to be achieved by throwing overboard the dead cultural baggage of which Europeans were ridiculously proud and wiping out all its deceitful isms: "L'état social actuel est inique et bon à détruire" 'Our present social state is iniquitous and should be destroyed'(Euvres complètes 4: 62); "Il faudrait fermer les écoles, brûler les musées, détruire les livres, briser les rotatives des imprimeries" 'We should close down schools, burn museums, destroy books, and smash printing presses' (8: 187). This purging is envisaged by Artaud in visceral terms, particularly the notion of hunger. Artaud formulates an anorexic cultural organism that is also an autoexoticist body. The cultural organism can best be reinvigorated by giving it the pangs of hunger, which will push the culture's vital energies to extreme intensity. "Le plus urgent [. . . est] d'extraire de ce que l'on appelle la culture, des idées dont la force vivante est identique à celle de la faim" 'What is most important [... is] to extract, from what is called culture, ideas the living force of which is identical to that of hunger' (4: 11). This hunger is not for something, not a desire that arises out of lack and that can be satisfied; it is an "appétit de vie" 'appetite for life' (122), which is the very incarnation of the implacable, cruel necessity of existence. What Artaud wants is a pure, insatiable hunger without any object. He declares on various occasions:

Je n'aime pas les poèmes de la nourriture mais les poèmes de la faim.

I love not poems of food but poems of hunger.

Il faut S'ABSTENIR dans la nourriture.

\author{
One must ABSTAIN from food. \\ Je sens l'appétit $d u$ ne pas être. \\ I simply hunger not to be.
}

The living force of culture is regained by hungering for nothing and purging the organism. Note Artaud's conflated way of speaking about the cultural organism and his own body. As critics such as Francine Vidieu-Larrère and Camille Dumoulié have observed, Artaud sees his body in cosmic dimensions ("J'avais un corps capable sur le plan cosmique" 'I had a body adequate to the cosmic level' (Euvres complètes 14: 166). That his body is a microcosmic version of the world and that culture is conversely the macrocosmic version of his body explains his analogy between purging culture and purging his body for the purpose of revitalization. The negative sign of food as hunger becomes a fasting, anorexic diet directed toward purity and death. By refusing food, the body becomes not only cleansed but also autonomous, for it does not depend on anything other than itself to exist. Artaud writes:

Je suis plein et ne supporte pas que quoi que ce soit me pénètre ni entre en moi, je ne prends pas, je ne bois pas, je ne mange pas, j’éjacule.

I am full and cannot stand anything to penetrate or enter me; I take nothing, drink nothing, eat nothing, I ejaculate.

Artaud's body becomes impermeable, emetic only, receiving nothing from outside. It exoticizes itself-that is, expels itself from itself-by submitting to a cathartic hunger that brings about therapeutic effects.

The connections between the body, culture, fasting, and autoexoticism are further articulated in Artaud's CSO, "corps sans organes" 'body without organs,' the autophagous and pure-surface body paradigm formulated in his late works. ${ }^{1}$ The CSO is not 
only anorexic and autonomous, it is also an indivisible whole that is exemplary of autopoiesis, or "auto-création," in Jacob Rogozinski's words (134). Artaud defines the CSO:

Le corps est le corps
il est seul
et n'a pas besoin d'organes.

(Pour en finir 167)

The body is the body

it is alone

and has no need of organs.

The CSO is thus a body against anatomyagainst, that is, the cutting or division of the body - and against instrumentalization (órganon, "instrument, tool"). Artaud's conceptualization of the CSO, true to his abhorrence of cultural categories and institutions, which divide the living cultural corpus into separate parts, is averse to the anatomical view of the body that demarcates the latter into constituent organs. Since the CSO is a holistic unit, Artaud makes sure that it remains impenetrable and a pure surface without interiority:

Le corps sans profondeur,

bouché,

sans perspective.

The body without depth,

plugged up,

without perspective.

Et le squelette est en surface, ...

C'est le dehors qui est le squelette. (12: 177)

And the skeleton is on the surface,...

It is the exterior that is skeleton.

His CSO is thus without interior or exterior yet is both interior and exterior, a body that is self-exiling, or autoexoticizing, as well as self-containing. To achieve such a body, the notions of pure hunger without lack and of anorexic purification are necessary: for an absolute existence like the CSO does not need food because it depends on nothing. It nourishes and re-creates itself by eating itself; its anorexic purification is simultaneously its cannibalistic autopoiesis. Artaud's idea about the purging and revitalization of culture therefore coincides with the CSO's selfcannibalism and self-regeneration. The CSO is simultaneously Artaud's ideal body, his own physical body in the process of self-perfection, and the macrocosmic body of culture. Yet Artaud's anorexic CSO is not a refusal of knowledge or refusal to learn about other cultures. Firstly because it needs nothing to complete itself and already embodies perfect knowledge; secondly because it breaks down the distinctions between different cultures and already encompasses the other. Since the CSO has neither interior nor exterior, it is a surface that allows maximal inclusion and has both self-knowledge and cosmic knowledge, enveloping all externalities and internalizing them, just as it externalizes its interiority completely. As a cultural organism, the CSO thus becomes an interface that can connect to diverse exotic others, nonoccidental cultures in particular, from Artaud's anti-European viewpoint. Only then does culture become identical with the totality of life, and only then can it start anew. In sum, Artaud's CSO goes from self-desire (pure hunger) through self-fashioning (autopoiesis) to self-exoticism (autoexoticism). This is an autoexotic idea of culture par excellence, for it encapsulates both the same (autós) and the different (exotikós) in its double movement between exoticizing the self as other and retrieving the other as exoticized self.

\section{Artaud's Cannibalistic Autoexoticism and Skins of Cultural Identity}

Despite the anorexic purging of the CSO's cultural organism envisaged by Artaud, the CSO is also paradoxically cannibalistic, a bottomless container that devours everything that is other. This paradox is in fact consistent with the CSO's ability to merge opposites while still keeping them opposite. 
Artaud's love of self-contradiction-noted by critics, who argue that we should not dismiss the incoherence in his thought ${ }^{2}$-is evident in his preference for interesting ideas over self-justifying arguments and his deliberate device of paradox, used to illustrate his belief in coincidentia oppositorum ("coincidence of opposites"), as elaborated in his Héliogabale and writings on oriental cultures (Euvres complètes, vol. 8). Unsurprisingly, therefore, in one passage, Artaud may approve of fasting and hunger; in another, he may demand to eat until satiation (e.g., 23: 27 and 112). Thus Artaud's anorexic autoexoticism has a doppelgänger: cannibalistic autoexoticism.

One important manifestation of this cannibalism is Artaud's references to eating other beings and to nourishing oneself "de choses de choix" 'with select things' for self-enrichment (23: 196). For instance, he declares:

Je mangerai le corps d'un lama grillé, le corps d'une vierge, le corps d'un brahmane, le corps d'un rabbin, ... Car je suis un cuisinier.

I will eat the body of a grilled lama, the body of a virgin, the body of a brahmin, the body of a rabbi,... Because I am a cook.

Chaque vie plus forte passe à travers les autres, donc les mange dans un massacre qui est une transfiguration et un bien.

(Euvres [Grossman] 568)

Each stronger life overpowers the others, consuming them in a massacre that is a transfiguration and a virtue.

Apart from the violence of Artaud's typically disorienting language, such statements are obscure in meaning. But if we take into account the fact that Artaud asserts an absolutely corporeal existence that is capable of assimilating everything, we start to understand that his voraciousness is not only an emotional expression but also a tendency toward cultural cannibalism, toward ever stronger and richer forms of life. His imagery of cooking and eating human beings, especially those with religious or cultural significance, is similar to the kind of anthropophagy that the Brazilian modernist poet Oswald de Andrade expounded in his 1928 "Manifesto antropófago" 'Cannibalist Manifesto.' Andrade refers to Montaigne's essay "Des cannibales" ("Of Cannibals") and the notorious story of the Brazilian Tupinambá eating European missionaries, praising the Tupinambá as the symbol of the extraordinary ability of Brazilian culture to assimilate others:

Só a antropofagia nos une....

Quase tudo nos dá apetite, desde as sinfonias até as epopeias, sistemas filosóficos e teorias científicas, .... No temos nenhum medo de com isso comprometer nossa identidade, primeiro porque identidade coisa de antropólogo, e costumamos comer todos os antropólogos, e segundo porque nossa identidade, ... [é] constituda precisamente ... pelo que vem de fora, pelo que recebemos.

Só me interessa o que não sou eu.

(Ruffinelli and Rocha 27, 52)

Only cannibalism unites us....

Almost everything gives us appetite, from symphonies to epics, philosophical systems and scientific theories.... We are not afraid of compromising our identity by this [cannibalism], first because identity is the anthropologist's thing, and we are used to eating all anthropologists; and second because our identity ... [is] constituted precisely by what comes to us from outside, by what we receive. Only what I am not interests me.

Andrade calls for a cultural anthropophagy that demands that Brazilians aggressively devour European cultural paradigms. Only then can Brazilian culture assert itself against the powerful European cultures and the colonial legacy of Europe. If Europe is strong, 
Andrade argues, then so much the better, because by eating Europe, Brazil will gain in strength. Through the metaphor of digestion, Andrade emphasizes that you assimilate the other into your cultural system, thereby transforming the other into something distinctly your own. This is why the other is not to be feared as an invasion of the self.

Andrade's notion of devouring culture and identity sheds light on Artaud's statements about eating people from other cultures, for it shows an "epistemologia do saber excêntrico" 'epistemology of $e c$-centric knowledge' that embraces other cultures (Ruffinelli and Rocha 53). That Artaud is a cultural cannibal is confirmed on numerous occasions when he shows his love and knowledge of non-European texts, esoteric thought, and cultural systems. An avowed autodidact, he had an attitude of cultural syncretism toward all cultures and thought traditions (especially the nonoccidental and nonmodern) and ravenously read translations of an incredibly wide range of texts. He drew inspiration from Chinese Taoist and classical literature, tantric Buddhism, Hindu philosophies, the Kabbalah, Syriac and Zoroastrian religions, medieval alchemy, Byzantine literature, the Egyptian Book of the Dead, the Aztec Popol Vuh, and Amerindian shamanism. Like the omnivorous Brazilian cannibal, Artaud lusts for more of other, exotic cultures (exotic in both senses, non-European and external), plucking different ideas and expressions from them for his own thought and experience. The result is that he builds a kaleidoscopic knowledge and thought that is constituted by many different cultures yet at the same time distinctly Artaudian. From desiring exotic others to absorbing them completely into his own circulation, Artaud is an exoticist who assimilates the other to transform himself instead of using the other to reinforce himself. He is autoexoticist in the active, metamorphic, and processual sense of changing the self by incorporating the other.
This cannibalistic autoexoticism places Artaud in an ever-shifting and uncertain position. His epistemological eclecticism is a "cultural practice aimed at displacing frontiers" (Bellei 93), which means that as a cannibal he is "in a perennial state of . . . incompleteness-and thus openness" (Budasz 12). Throughout his life and work he occupied shifting and uncertain positions toward French and European culture, and switched among multiple identities and selves. That Artaud is only notionally French is well known, since his family was Greek and came from Smyrna, and he grew up in a polyglot environment. As his writing career developed, he refused to be identified as French or European and ultimately refused to be defined by anything other than himself. Cultural identity was a play of masks for him. Nanaqui, Antoneo Arlanapulos, Antonin Nalpas, François Salpan, Arto, AR-TAU, le mômo-these were all names he used for himself. He also played on his mother's name, Euphrasie, seeing it as a combination of Europe and Asie, thereby claiming a Eurasian genealogy that allowed him to inhabit different cultures and identities. On various occasions, he insisted that he was Greek, Irish (Euvres [Grossman] 849, 868), or even Chinese. He felt that he had completely fused with the Tarahumara Indians in Mexico, finally becoming this absolute CSO that is both cosmic and self-identical. Artaud, besides his theater of participation rather than alienation, is always completely implicated in the culture or phenomena he is contemplating and experiencing (e.g., his participation in the Tarahumaran peyote rites). He shifts perspectives when in different circumstances and sheds cultural identities like masks. Ultimately, the ensemble of his different identities are an exotic but sui generis construction: Artaud is Greek, Turkish, French, Mexican, Indian, Chinese, and Irish all at once, yet he belongs to nothing but himself. "L'infini c'est moi" 'I am the infinite' (Euvres complètes 26: 
92), he asserts, as well as, "Moi, Antonin Artaud, je suis mon fils, mon père, ma mère, / et moi" 'I, Antonin Artaud, I am my son, my father, my mother, / and myself' (Euvres [Grossman] 1152).

\section{Toward an Artaudian Autoexoticism}

Artaud's idea of culture is inextricably intertwined with his notion of the body organism, food and diet metaphors, and his transformation of knowledge and cultural identity. In an interesting parallel to Lévi-Strauss's categories of anthropophagic and anthropoemic societies, his views delineate a culture of anorexic self-absorption and a culture of omnivorous extroversion. For Artaud, it is precisely because both eating and knowing need to exist between and through physical and mental interstices, because they both are penetrating and porous practices, that they can embody the movements of the cultural organism: to internalize all foreignness and transform itself to accommodate this new foreignness in itself, to unblock all bodily orifices and expose one's substance and subjectivity to change. This is how Artaud may help us conceptualize a kind of autoexoticism that has positive epistemological and ethical value. An Artaudian auto-exoticist throws oneself and one's own culture open to revision, thereby dislodging the centrality of the self and cultural hierarchy. One also refuses any exoticism that essentializes cultural differences, since one desires the other not because it is fundamentally unassimilable and lacking in oneself but because one sees in it a new facet of the world, an opportunity to learn something new, and further possibilities for self-fashioning and self-enrichment. This way of being autoexoticist is not about maintaining an unbridgeable chasm between the self and other but about creating a holistic field of intercultural experience. In this field, one is able not only to shift perspectives between the self and other but also to change the categorical boundaries that decide what can be included as self and excluded as other. As in a food web, diverse bodies and systems participate equally but hold roles that can be displaced and reassigned. According to the anthropologists Beth Conklin and Aparecida Vilaça, the changing of perspectives inside a food web can be illustrated in Amazonian Wari cannibalism, which involves

a complex system of beliefs, in which the consumption of enemies killed or captured in combat ("outside" cannibalism) and the consumption of a member of their own group ("inside" cannibalism) were related to the ever present concept of jam, which could be translated as the spirit,... or essence of creatures.... Killing, cooking, and eating change the jam of things.... Predators can become prey, friends become enemies, and dead relatives can come back to life. It places all living beings in an eternal and balanced cycle of eating and being eaten.

(Budasz 12-13)

The Artaudian autoexoticist's world is a version of such a symbolic food web, where what is considered self and other are transient and plastic. After all, these categories are constructed depending on your standpoint and the specific context. The boundaries between perceived cultural, ontological, and conceptual entities can therefore all be renegotiated. The autoexoticist eats a diet of different cultures and consciously selects and re-creates elements and aspects from disparate traditions and identities. The result is an eclecticism that is intentionally constructed rather than passively imposed. In keeping with Artaud's view of culture as a malleable body with vital forces flowing in and out constantly but still being genuinely itself, we may contemplate an autoexoticism that enables an extraordinary fluidity of self and becomes a powerful means to assert agency in shaping one's own knowledge and culture. 


\section{NOTES}

Translations are mine unless otherwise indicated.

1. Deleuze and Guattari wrote about the Corps sans Organes, inspired by Artaud, but the Deleuzian CsO is fundamentally different from Artaud's CSO (see my "Preserving"). Here I limit my discussion to Artaud's CSO without the Deleuzian appropriation-interpretation.

2. Among these critics are Grossman; Mèredieu; Derrida; and Morfee.

\section{Works Cited}

Artaud, Antonin. Euvres. Edited by Evelyne Grossman, Gallimard, 2004.

-. Euvres complètes. Vols. 1-26, Gallimard, 1976-94. . Pour en finir avec le jugement de dieu. Gallimard, 2003.

Bellei, Sergio. "Brazilian Anthropophagy Revisited." Cannibalism and the Colonial World, Cambridge UP, 1998, pp. 93-95.

Budasz, Rogério. "Of Cannibals and the Recycling of Otherness." Music and Letters, vol. 87, no. 1, Jan. 2006, pp. 1-15.

Deleuze, Gilles, and Félix Guattari. Mille Plateaux. Éditions de Minuit, 1980.
Derrida, Jacques. "Artaud, oui...." Antonin Artaud, special issue of Europe: Revue littéraire mensuelle, nos. 873-74, Jan.-Feb. 2002, pp. 23-38.

Dumoulié, Camille. Antonin Artaud. Seuil, 1996.

Grossman, Evelyne. La défiguration: Artaud-BeckettMichaux. Éditions de Minuit, 2004.

Lévi-Strauss, Claude. Le cru et le cuit. Plon, 1964. Vol. 1 of Mythologiques.

. Tristes tropiques. Plon, 1955.

Li, Xiaofan Amy. "Preserving Life Force: Antonin Artaud and Zhuangzi on the Body." Preservation, Radicalism, and the Avant-Garde Canon, edited by Rebecca Ferreboeuf et al., Palgrave Macmillan, 2016, pp 153-69. Springer Link, link.springer.com/chapter/10.1057\%2F 9781137474377_9.

Mèredieu, Florence de. Antonin Artaud: Les couilles de l'ange. Blusson, 1992.

Morfee, Adrian. Antonin Artaud's Writing Bodies. Oxford UP, 2005.

Rogozinski, Jacob. Guérir la vie: La passion d'Antonin Artaud. Éditions du Cerf, 2011.

Ruffinelli, Jorge, and João Cezar de Castro Rocha, editors. Antropofagia hoje? Oswald de andrade em cena. Realizaçoes Editora, 2011.

Vidieu-Larrère, Francine. Lecture de l'imaginaire des cuvres dernières de Antonin Artaud. Lettres Modernes Minard, 2001. 